\title{
LAHIRNYA PERDA BERBASIS SYARI'AH DI PROVINSI KALIMANTAN SELATAN
}

\author{
Hayatun Na'imah \\ Dosen tetap pada Fakultas Syari'ah dan Ekonomi Islam IAIN Antasari dengan Konsentrasi Kajian \\ Ilmu Hukum Tata Negara
}

\begin{abstract}
The emergence of Shariah-based local regulations raises the pros and cons in the community. For the people which is pro-sharia based regulation, the birth of local regulations is regarded as a breakthrough to ensure an orderly society, both in terms of the relationship between individuals, as well as assuredness "moral" of the individual in society. For the ones who oppose this regulation, they argue that the establishment of Shariah-based regulations considered excessive, and some even declare openly that the local regulations are contrary to the existlaws. Shariah-basedregulationscannot say inherently good or not according to the law. There are several parameters that can be done to make an assessment, in particular by the Executive Review conducted by the Ministry in State, Judicial Review conducted by the Supreme Court and the Legislative of Review by the Legislature.
\end{abstract}

Abstrak: Munculnya Perda-perda berbasis syari'ah demikian memunculkan pro dan kontra di masyarakat. Bagi kalangan yang pro-perda berbasis syari'ah, lahirnya perda-perda tersebut dianggap sebagai terobosan untuk menjamin tertib masyarakat, baik dari sisi hubungan antar individu, maupun keterjaminan "moral" individu tersebut di masyarakat. Bagi kalangan yang kontra dengan Perda ini, mereka mengargumenkan bahwa pembentukan Perda berbasis syari'ah dinilai berlebihan, bahkan ada yang menyatakannya secara terbuka bahwa perda-perda tersebut bertentangan dengan peraturan perundang-undangan yang ada. Perda barbasis syari'ah tidak dapat langsung dikatakan baik atau tidak menurut hukum, begitu juga tidak dapat dikatakan sejalan atau bertentangan dengan peraturan perundang-undangan yang ada. Ada beberapa parameter yang dapat dilakukan untuk melakukan penilaian, yaitu dengan cara Eksekutif Review yang dilakukan oleh Kementrian Dalam Negeri, Judicial Review dilakukan oleh Mahkamah Agung dan Legislatif Review oleh Lembaga Legislatif.

Kata kunci: legislative, Perda, Syari'ah, otonomi.

\section{Pendahuluan.}

Bagi Kalimantan Selatan, tanggal 1 Januari 1957 benar-benar merupakan momentum penting dalam sejarahnya, mengingat pada tanggal itu Kalimantan Selatan resmi menjadi provinsi yang berdiri sendiri di Pulau Kalimantan, bersama-sama dengan Provinsi Kalimantan Timur dan Provinsi Kalimantan Barat. Sebelumnya ketiga provinsi tersebut berada dalam satu provinsi, yaitu Provinsi Kalimantan.

Sebelum menjadi provinsi yang berdiri sendiri, sesungguhnya Kalimantan Selatan sudah merupakan daerah yang paling menonjol di Pulau Kalimantan, khususnya Kota Banjarmasin yang merupakan pusat kegiatan politik, ekonomi/ perdagangan, dan pemerintahan, baik semasa penjajahan maupun pada awal kemerdekaan.
Perkembangan kehidupan pemerintahan dan kenegaraan di daerah Kalimantan Selatan sampai dengan permulaan abad 17 masih sangat kabur karena kurangnya data sejarah. Adanya Hikayat Raja-Raja Banjar dan Hikayat Kotawaringin tidak cukup memberikan gambaran yang pasti mengenai keberadaan kerajaan-kerajaan tersebut. ${ }^{1}$

Namun demikian, berdasarkan kedua hikayat tersebut dapat diketahui bahwa pada abad 17 salah satu tokoh yaitu Pangeran Samudera yang kemudian bergelar Sultan Suriansyah (cucu Maharaja Sukarama) dengan dibantu para Patih bangkit menentang kekuasaan pedalaman Nagara Daha dan menjadikan Banjarmasin di pinggir

\footnotetext{
Najib Kaelani, Islam dan Perlawanan di Kalimantan Selatan dan Tengah pada abad 19 dan awal abad 20, (Kalimantan Selatan; Pusat Studi dan Pengembangan Borneo, 2002) hlm 1.
} 
Sungai Kuin sebagai pusat pemerintahannya (daerah ini disebut Kampung Kraton). ${ }^{2}$

Melekatnya ajaran Islam pada Masyarakat Banjar dimulai dengan pemberontakan Pangeran Samudera merupakan pembuka jaman baru dalam sejarah Kalimantan Selatan sekaligus menjadi titik balik dimulainya periode Islam dan berakhirnya jaman Hindu. Sebab dialah yang menjadi cikal bakal Islam Banjar dan pendiri Kerajaan Banjar. ${ }^{3}$

Dalam perkembangan sejarah berikutnya, pada tahun 1859 seorang Bangsawan Banjar yaitu Pangeran Antasari mengerahkan rakyat Kalimantan Selatan untuk melakukan perlawanan terhadap kaum kolonialisme Belanda meskipun akhirnya pada tahun 1905 perlawanan-perlawanan berhasil ditumpas oleh Belanda. ${ }^{4}$

Kelancaran hubungan dengan Pulau Jawa turut mempengaruhi perkembangan di Kalimantan Selatan. Tumbuhnya pergerakan-pergerakan kebangsaan di Pulau Jawa dengan cepat menyebar ke daerah Kalimantan Selatan, hal ini tercermin dengan dibentuknya wadah-wadah perjuangan pada tahun 1912 di Banjarmasin seperti berdirinya cabangcabang Sarikat Islam di seluruh Kalimantan Selatan. Seiring dengan itu para pemuda Kalimantan Selatan terdorong membentuk Organisasi Kepemudaan yaitu Pemuda Marabahan, Barabai dan lainlain, yang kemudian pada tahun 1929 terbentuk Persatuan Pemuda Borneo. Organisasi-organisasi perjuangan tersebut merupakan wadah untuk menyebarluaskan kesadaran kebangsaan melawan penjajahan Kolonial Belanda.

Pada periode pasca Proklamasi Kemerdekaan merupakan momentum yang paling heroik dalam sejarah Kalimantan Selatan, dimana pada tanggal 16 Oktober 1945 dibentuk Badan Perjuangan yang paling radikal yaitu Badan Pemuda Republik Indonesia Kalimantan (BPRIK) yang dipimpin oleh Hadhariyah M dan A. Ruslan. Namun, dalam perjalanan selanjutnya gerakan perjuangan ini mengalami hambatan, terutama dengan disepakatinya perjanjian Linggarjati pada tanggal 15 Nopember 1945. Berdasarkan perjanjian ini ruang gerak pemerintah Republik Indonesia menjadi terbatas hanya pada kawasan Pulau Jawa, Madura,

\footnotetext{
2 Yusuf Halidi, Ulama Besar Kalimantan Selatan; Syekh Muhammad Arsyad Al Banjari, (Banjarmasin; Aulia, 1980) hlm 21.

3 Abdurrahman. Studi tentang Undang-undang Sultan Adam 1835 (Banjarmasin; STIH Sultan Adam, 1989) hlm 15.

${ }^{4}$ Yusuf Halidi, Op Cit, hlm 22.
}

dan Sumatera sehingga organisasi-organisasi perjuangan di Kalimantan Selatan kehilangan kontak dengan Jakarta, kendati akhirnya pada tahun 1950 menyusul pembubaran Negara Indonesia Timur yang dibentuk oleh kaum kolonial Belanda, maka Kalimantan Selatan kembali menjadi bagian yang tidak terpisahkan dari Republik Indonesia sampai saat ini. ${ }^{5}$

\section{Perkembangan Islam di Kalimantan Selatan}

Para ahli sejarah sepakat bahwa masuknya Islam ke Nusantara melalui jalan damai yaitu perdagangan, perkawinan, dan politik.

Jika diamati dari periodisasi perkembangan islamisasi di Kalimantan Selatan, Nampak jelas bahwa perkembangan Islam setelah masuk dalam institusi negara terlihat sangat masif. Struktur organisasi Kerajaan Banjar menempatkan institusi berbasis agama di bawah satu tingkat di bawah raja.

Agama memiliki peran yang sangat luas di dalam masyarakat. Pemimpin-pemimpin agama Islam, secara struktur menempati posisi dan duduk sebagai bangsawan. Sementara kekuasaannya adalah meliputi semua kegiatan para pedagang, rakyat umum, dan para petani di dalam negeri. Pada masa konsolidasi agama Islam, Sultan Suriansyah menugaskan Kiai Palabuhan atau disebut juga Mantri Bandar dengan 100 (seratus) anak buah. Mereka bertugas untuk menjalankan kegiatan pemungutan bea cukai pelabuhan. ${ }^{6}$

Ketika Sultan dijabat Marhum Panambahan Kacil (1595-1620) kaum bangsawan mempunyai gelar Raden dan Pangeran dan selalu ikut serta dalam segala sidang negara yang membicarakan masalah-masalah negara. Struktur pemerintahan saat itu terdiri atas jabatan Mangkubumi, Mantri Pangiwa-Panganan, Mantri Jaksa, Tuan Panghulu, Tuan Khalifah, Khatib, Para Dipati, dan Para Priyai.

Persoalan-persoalan yang muncul di bidang agama dibicarakan oleh kalangan-kalangan atas. Biasanya yang ikut dalam pembicaraan itu adalah Mangkubumi, Dipati, Jaksa, Khalifah, dan Penghulu yang memimpin pembicaraan adalah Panghulu. Jabatan Panghulu mempunyai status yang tinggi dalam negara. Dalam hierarki struktur negara, kedudukan Panghulu adalah di bawah Mangkubumi. Pada masa itu penghulu ditugasi dalam mengurus masalah keagamaan semata, sedangkan masalah

\footnotetext{
5 https://id.wikipedia.org/wiki/Badan-Badan_ Pemberontakan_Rakyat_Kalimantan_Selatan, hlm 1 diakses 15 Agusrus 2015 jam 12.25 Wita.

${ }^{6}$ Ideham, Sejarah Banjar, Op. Cit, hlm 111.
} 
lainnya diurus oleh Jaksa. Kerajaan Banjar memakai sistem ini sampai pergantian dari Kerajaan Islam Banjar awal hingga diganti oleh Sultan Musta'in Billah. $^{7}$

Sultan Adam al Wasik Billah yang memerintah pada permulaan abad XIX M mengadakan sejumlah perubahan-perubahan struktur. Secara hierarki dimulai dari Mufti, Hakim Tertinggi, Pengawas Pengadilan Umum; Qadi; Kepala Urusan Hukum agama Islam; Penghulu, Hakim Rendah; Lurah, langsung sebagai Pembantu Lalawangan dan mengamati pekerjaan beberapa orang Pambakal (Kepala Kampung) dibantu oleh Khalifah, Bilal, dan Kaum; Pambakal, Kapala Kampung yang menguasai beberapa anak kampung; Mantri, Pangkat kehormatan untuk orang-orang terkemuka dan berjasa, diantaranya ada yang menjadi kepala desa dalam wilayah yang sama dengan Lalawangan; Tatulia Kampung, orang yang terkemuka di kampung; dan Panakawan, orang yang menjadi suruhan raja, dibebas dari segala macam pajak dan kewajiban. ${ }^{8}$

Perubahan ini tidak mengubah posisi penting institusi yang menjalankan kewenangan dalam bidang agama Islam. Kewenangan-kewenangan yang berkaitan dengan agama Islam masih ditempatkan pada posisi penting struktur organisasi kerajaan. Struktur organisasi dari pemerintahan awal hingga masa pemerintahan Musta'in Billah tidak mengalami perubahan secara signifikan. Baru ketika Sultan Musta'in Billah naik tahta struktur organisasi kerajaan lebih kompleks.

Pada masa pemerintahan Sultan Adam alWasik Billah (1826-1857) terjadi perubahan besarbesaran di Kerajaan Banjar. Dimana saat itu Belanda telah merebut sebagian kekuasaan Kerajaan Banjar. Wilayah Kekuasaan Banjar terpecah-pecah, sebagian memang masih di bawah kekuasaan Banjar, namun sebagian besar telah dikuasai Belanda. Pengaruh raja sudah mulai berkurang di mata rakyat.

Secara berangsung-angsur wilayah kekuasaan Kerajaan Banjar mulai menyempit. Dimulai pada tahun 1787, yang hilang direbut Belanda, terus berkurang pada tahun 1826, hingga menjadi sangat sempit yang hanya meliputi wilayah yang dihuni oleh kelompok etnik suku Banjar di bawah pemerintahan Sultan Adam al-Wasik Billah.?

\footnotetext{
Ibid., hlm. 14.

${ }^{8}$ Kiai Amir Hasan Bondan, Sulub Sedjarah Kalimantan, (Banjarmasin; Fajar, 1953) hlm. 149-150.

9 Ideham, Sejarah Banjar, Op.Cit, hlm 17.
}

Berdasarkan uraian di atas agama Islam diperkirakan mulai masuk ke Kalimantan Selatan pada abad ke 14 dan abad ke 15. Sejak dianut oleh keluarga Kerajaan Banjar, agama Islam semakin tersebar luas ke tengah masyarakat, mayoritas penduduk Kalimantan Selatan terutama suku Banjar beragama Islam.

Penduduk yang mendiami Kalimantan Selatan pada masa lalu dan masa sekarang dalam kaitan dengan masyarakat Banjar, yaitu;

1. Bahwa etnik melayu merupakan etnik yang dominan dengan karakteristik beragama Islam;

2. Bahwa di samping ini dikenal kelompok masyarakat yang disebut dengan suku Dayak yang umumnya tinggal di daerah pedalaman dan beragama 'Kaharingan'.

Dengan kenyataan tersebut umumnya yang di sebut 'Urang Banjar' adalah dari etnik melayu yang beragama Islam, sehingga ada suatu suku Dayak 'Bakumpai' yang tinggal di daerah Batola (Marabahan) yang sudah menganut agama Islam tidak mau lagi disebut sebagai 'Urang Dayak'10

\section{Kebijakan Politik Lahirnya Perda Berbasis Syari'ah di Kalimantan Selatan.}

Setelah diterapkannya Otonomi Daerah yang ditandai dengan diberlakukannya Undang-undang No. 22 Tahun 1999 tentang Pemerintahan Daerah sejak 1 Januari 2001 yang kemudian diganti dengan Undang-undang No. 32 Tahun 2004 tentang Pemerintahan Daerah, setiap daerah (provinsi, kabupaten/kota) diberikan kewenangan yang sangat besar untuk mengatur dan memerintah daerahnya masing-masing.

Peluang yang diberikan oleh kebijakan Otonomi Daerah itu diterjemahkan beragam oleh daerah. Salah satu "terjemah" yang dipakai adalah dengan membuat beragam Peraturan Daerah (Perda). Di beberapa daerah, termasuk di Kalimantan Selatan, terdapat fenomena pembuatan Perda yang menarik untuk dikaji secara akademik, khususnya dari perspektif Hukum Tata Negara. Fenomena tersebut adalah munculnya banyak Perda yang mengatur persoalan-persoalan terkait dengan keberagamaan seseorang dan/atau kelompok di masyarakat, diantaranya adalah Perda Kabupaten

\footnotetext{
${ }^{10}$ Tim Penelitian Puslit Unlam, Hukum Adat Kalimantan, BAPEDA Tingkat I, Kalsel, Banjarmasin, 1990, hlm 38, dikutip dari, Gusti Muzainah, Asas Kemanfaatan tentang Kedudukan Perempuan dalam Hukum Waris Adat Masyarakat Banjar ( Yogyakarta; Pustaka Akademika, 2016) hlm 79
} 
Banjar No. 4 Tahun 2005 tentang Kewajiban Pandai Baca Tulis Al Quran bagi siswa/siswi SD/ MI sederajatnya dan Perda Kota Banjarmasin No. 6 Tahun 2004 tentang Larangan Minuman Keras (Miras) di Kota Banjarmasin. ${ }^{11}$ Perda-perda demikian sering disebut sebagai perda berbasis syari'ah.

Munculnya Perda-perda berbasis syari'ah demikian memunculkan pro dan kontra di masyarakat. Bagi kalangan yang pro-perda berbasis syari'ah, lahirnya perda-perda tersebut dianggap sebagai terobosan untuk menjamin tertib masyarakat, baik dari sisi hubungan antar individu, maupun keterjaminan "moral" individu tersebut di masyarakat. Bagi kalangan yang kontra dengan Perda ini, mereka mengargumenkan bahwa pembentukan Perda berbasis syari'ah dinilai berlebihan, bahkan ada yang menyatakannya secara terbuka bahwa perda-perda tersebut bertentangan dengan peraturan perundang-undangan yang ada.

Secara umum, kelahiran sebuah Perda berbasis syari'ah di daerah tidak terlepas dari peran pimpinan daerah tersebut (seperti gubernur/ bupati/walikota). Hal ini dapat dilihat dengan banyaknya Perda berbasis syari'ah yang lahir dari usulan eksekutif, padahal di era reformasi ini sudah seharusnya peran legislatif harus lebih menonjol dalam inisiatif pembuatan Peraturan Daerah karena sifatnya sebagai wakil rakyat yang menyerap aspirasi rakyat di daerah. Di daerah-daerah yang mayoritas masyarakatnya beragama Islam ditambah dengan budaya Islam yang kental dilaksanakan, menjadi kesempatan bagi gubernur/bupati/walikota daerah tersebut untuk melegetimasi lahirnya Perda-perda berbasis syari'ah.

Kemunculan Perda berbasis syari'ah yang tibatiba dan cenderung elitis mengindikasikan adanya kepentingan politis terkait dengan pencalonan

\footnotetext{
${ }^{11}$ Perda tersebut berisi larangan menjual, mendistribusikan, menyimpan, mempromosikan dan mengkonsumsi miras ini diidentikkan dengan Perda berbasis syari'ah, karena pelarangan minum khamar (minuman keras) terdapat dalam ajaran Islam. Sebelumnya terdapat Perda Provinsi Kalsel No. 1 Tahun 2000 tentang Larangan minuman beralkohol yang dibatalkan oleh Pemerintah Pusat. Pasalnya, Perda itu dianggap bertentangan dengan PP No. 13 Tahun 1995 tentang Izin Usaha Industri dan PP No. 25 Tahun 2000 tentang Kewenangan pemerintah dan kewenangan provinsi sebagai daerah otonom, serta Keputusan Presiden No. 3 Tahun 1997 tentang Pengawasan dan pengendalian minuman beralkohol, diakses dari www.zfikri.wordpress.com pada 09 Pebruari 2008.
}

kembali anggota dewan ataupun Kepala Daerah.

Musdah Mulia menyebutkan, ${ }^{12}$ bahwa kemunculan Perda berbasis syari'ah hanyalah alat untuk memperoleh dan melanggengkan kekuasaan semata, Perda syari'at sebagai kendaraan politik untuk meraih jabatan tertentu.

Perda berbasis syari'ah muncul pada momenmomen mendekati Pilkada. Kemunculan Perda tersebut lebih banyak sebagai daya tarik bagi masyarakat untuk memilihnya kembali sebagai pejabat. Apabila diliat dari segi waktu kemunculan Perda berbasis syari'ah terjadi menjelang Pilkada dengan maksud untuk menarik simpati masyarakat.

\section{Perda Berbasis Syari'ah}

Fenomena munculnya Perda berbasis syari'ah di berbagai daerah di Indonesia satu mata rantai dengan kemunculan Otonomi Daerah. Kewenangan besar yang diberikan kepada daerah, baik provinsi maupun kabupaten/kota dimanfaatkan oleh sebagian daerah untuk membuat Perda dengan maksud melindungi, mempertahankan dan/atau menjaga berbagai karakteristik khas daerahnya.

Bagi daerah-daerah yang mayoritas muslim, antara agama Islam dan budaya masyarakat setempat telah berjalan bersamaan, bahkan telah menyatu selama puluhan bahkan ratusan tahun. Daerah-daerah demikian memprakarsai beberapa Perda berbasis syari'ah, seperti Perda tentang Kewajiban Khatam Al Qur'an bagi anak usia SD/ MI, Perda tentang Ramadhan, Perda tentang Jumat Khusu' dan berbagai Perda lainnya. Perda-perda demikian populer disebut sebagai Perda berbasis syari'ah.

Walaupun demikian, pembentukan Perda berbasis syari'ah memerlukan analisis yang lebih dalam dari aspek hukum, khususnya Hukum Tata Negara. Sebab Perda merupakan produk hukum yang harus tunduk dan patuh terhadap kaidahkaidah pembuatan produk hukum dan tertib hukum Indonesia.

\section{Penutup}

Beberapa aspek untuk melihat Perda-perda Berbasis Syari'ah dapat diterima, atau bahkan bertentangan secara yuridis dilihat dari sudut pandang Hukum Tata Negara Indonesia.

Pertama: Dari sisi tertib hukum Indonesia

\footnotetext{
${ }^{12}$ Disampaikan dalam seminar bartajuk," Peluang dan Tantangan Formalisasi Syari'at Islam di Indonesia (kasus Surakarta)" diselenggarakan oleh STAIN Surakarta, diakses dari http;//www.icrp-online.org. pada tanggal 15 Agustus 2015.
} 
sebagaimana dijelaskan di atas, Perda merupakan jenis peraturan yang berada paling bawah sesuai dengan Undang-undang No. 12 Tahun 2011 tentang Pembentukan Peraturan Perundang-undangan. Sehingga secara yuridis terdapat konsekuensi secara formil, maupun materiil, bahwa Perda tidak boleh bertentangan dengan peraturan perundangundangan yang lebih tinggi, seperti undang-undang (UU). Undang-undang No. 32 Tahun 2004 tentang Pemerintahan Daerah sebagaimana dijelaskan sebelumnya, masalah agama merupakan domain Pemerintah Pusat, bukan Pemerintah Daerah. Sehingga jika Perda berbasis syari'ah sama dengan Perda yang mengatur perihal persoalan-persoalan agama, kendati lingkupnya lokal, maka secara tertib hukum nasional dianggap bertentangan dan wajib dinyatakan tidak berlaku.

Kedua : Dilihat dari sisi materi Perda. Materi/ muatan yang diatur oleh Perda-perda berbasis syari'ah akan menentukan bertentangan atau tidaknya Perda tersebut secara yuridis. Materi Perda yang memuat persoalan agama jelas bertentangan dengan tertib hukum nasional, sebab bukan merupakan wewenang Pemerintah Daerah untuk mengaturnya. walaupun materi Perda yang dianggap bermuatan agama masih dapat diperdebatkan. Sebagai contoh Perda Kabupaten Banjar tentang Kewajiban Khatam Al Qur'an masih mengandung perdebatan, apakah kewajiban Khatam Al-Qur'an merupakan ranah agama atau dapat ditarik menjadi ranah pendidikan. Di Kalimantan Selatan terdapat kultur pendidikan, dimana anak-anak usia SD dan sederajatnya berkewajiban (secara budaya) untuk mengkhatamkan Al Qur'an. Hal ini terkait dengan budaya dan tradisi masyarakat Banjar yang dekat dengan budaya baca (termasuk tulis) Al Qur'an. Jika Perda demikian muatannya didekati dari sisi pendidikan, maka Perda demikian tidaklah bertentangan secara yuridis.

Hal ini berbeda dengan Perda berbasis syari'ah yang murni mengatur tentang persoalan agama dan bersifat privat, seperti Perda Jum'at Khusu'. Perda ini memuat tentang larangan membuat "keributan" pada saat sholat Jum'at dilaksanakan dengan tujuan agar orang yang melaksanakan sholat Jum'at dapat dengan khusu' melaksanakan ibadahnya. Persoalan khusu' adalah persoalan keagamaan dan sifatnya sangat privat. Hanya sang individu yang dapat merasakan khusu' atau tidaknya pada saat ia beribadah. Sangat aneh, jika persoalan khusu' ini ditarik oleh Pemerintah Daerah menjadi kewenangannya. Dari persfektif ini, materi Perda yang merupakan wilayah agama dan bersifat privat dapat dinyatakan bertentangan secara yuridis. Terlebih hukum (hukum positif) bertujuan untuk mengatur hubungan manusia dengan manusia semata, hubungan manusia dengan Tuhan tidak menjadi domain hukum positif.

Ketiga: Dilihat dari sisi legal drafting, adanya pencantuman sumber hukum Perda berupa Al Qur'an dan As Sunnah tidak sejajar dengan produk hukum Indonesia yang bukan negara agama. Pencantuman kedua sumber hukum tersebut membuat Perda-perda berbasis syari'ah "cacat" dilihat dari sisi tata cara penyusunan produk hukum (legal drafting), termasuk Perda. ${ }^{13}$

Keempat: Dari sisi penerapan sanksi, sebuah Perda hanya diperkenankan menerapkan sanksi administratif dan sanksi pidana, serta denda dalam batasan tertentu. Sanksi pidana misalnya tidak boleh melebihi 6 (enam) bulan penjara, sedangkan sanksi berupa denda maksimal sebesar Rp 50.000.000,(lima puluh juta rupiah) sebagaimana dijelaskan di atas. Jika terdapat Perda yang menerapkan sanksi di luar sanksi tersebut, termasuk sanksi-sanksi yang terdapat dalam hukum Islam untuk perbuatan tertentu.

Kelima : Dari aspek etika-moral hukum (law in ethic), pembuatan Perda berbasis syari'ah harus dilihat secara proporsional, terutama latar belakang dan kondisi pada saat Perda berbasis syari'ah itu dibuat. Sebagai contoh, di beberapa daerah ada Perda yang mendesak untuk dibuat justru di kesampingkan dan mendahulukan pembuatan Perda-perda berbasis syari'ah. Perda yang berkaitan dengan pelayanan publik, Perda anti korupsi dan berbagai Perda lain yang seharusnya menjadi prioritas tidak dikerjakan. Dalam kontek demikian, secara etika hukum, pembentukan Perda berbasis syari'ah mengundang tanda tanya besar. Terlebih di banyak kasus, pembuatan Perda berbasis syari'ah dibuat pada saat menjelang Pemilihan Kepala Daerah (Pilkada). Pembuatan Perda berbasis syari'ah dapat dimaknai sebagai cara penarikan simpati publik kepada penguasa dan diharapkan dari simpati itu akan muncul dukungan kembali untuk menjadikan penguasa yang ada (incumbent) duduk

\footnotetext{
${ }^{13}$ Sumber hukum yang diakui di Indonesia saat ini adalah : Pancasila, UUD 1945, Tap MPR, UU/Perpu, PP, Peraturan Presiden dan Perda (vide Pasal 7 ayat (1) UU No. 12 Tahun 2011 tentang Pembentukan Peraturan Perundang-undangan).
} 
kembali di kursi kekuasaannya. Dalam konteks ini, kekuasaan cenderung disalahgunakan untuk kepentingan jangka pendek sang penguasa (power tends to corrupts, absolute power corrupts absolutely). ${ }^{14}$

Hal lain yang juga harus mendapat perhatian dalam koridor etika-moral hukum dalam pembentukan berbagai peraturan perundangundangan, termasuk Perda adalah bagaimana terbentuknya berbagai peraturan tersebut dapat menciptakan tertib hukum nasional yang bermuara pada tertib masyarakat secara luas. Munculnya peraturan yang identik dengan kepentingan kalangan tertentu, lambat laun akan menimbulkan sentimen dari kalangan lain. Pada Negara Indonesia, antusiasme sebagian daerah yang mayoritas penduduknya muslim untuk membentuk Perdaperda berbasis syari'ah akan menimbulkan sentimen kalangan non-muslim untuk membentuk peraturan serupa di daerah-daerah yang menjadi basisnya. ${ }^{15}$ Jika fenomena ini terus berlanjut, maka kedepan yang menonjol adalah peraturan-peraturan berbasis kepentingan kelompok tertentu, sehingga peraturan yang menjunjung tinggi persamaan di depan hukum lambat laut akan tersingkirkan. Hal ini bukan tidak mungkin akan menimbulkan disintegrasi hukum nasional yang merupakan awal mula lahirnya disintegrasi bangsa. ${ }^{16}$

\footnotetext{
${ }^{14}$ Adagium ini muncul dari Lord Action, seorang pakar Politik dan Ketatanegaraan Inggris. Artinya : Kekuasaan cenderung disalahgunakan, kekuasaan yang absolut cenderung (ingin) bertahan selama-lamanya.

${ }^{15}$ Dalam suatu kesempatan K.H.Abdurrahman Wahid atau Gus Dur ( Presiden Republik Indonesia periode 19992001) pernah mengeluhkan penerapan Syari'ah Islam di Kabupaten Cianjur, Kabupaten Garut dan Kabupaten Tasikmalaya. Gus Dur mendesak pemerintah untuk bertindak meluruskan kembali Perda-perda Syari'at Islam tersebut. Semangat beragama itu tidak benar, katanya, menunjuk pada Pemda dan DPRD di tiga kabupaten itu yang menerapkan Syari'at Islam. Di Sumatera UMMAT KRISTEN pun melihat dengan cemas bagaimana 17 gereja ditutup di Aceh. Gereja Huria Kristen Indonesia Daerah IV di Kabupaten Aceh Singkil. Kini hanya 5 gereja yang masih berfungsi di sana. Ketujuh belas gereja yang ditutup itu berasal dari Gereja Kristen Protestan Pakpak Dairi, GKPPD, HKI dan Katholik. Dikutip dari Radio Nederland Wereldomroep, Jumat 03 Mei 2008 dalam www.zfikri.wordpress.com.

${ }^{16}$ Lihat asas-asas pembentukan peraturan perundangundangan dalam pasal 6 Undang-undang No. 10 Tahun 2004 tentang Pemerintahan Daerah. Diantara asas yang disebutkan adalah asas kebangsaan dan kenusantaraan. Kedua asas itu mengandung makna bahwa dalam pembentukan peraturan perundang-
}

Parameter Penilaian Perda Berbasis Syari'ah dari sisi Yuridis Ketatanegaraan.

\begin{tabular}{|c|c|c|}
\hline No & $\begin{array}{l}\text { Parameter } \\
\text { Penilaian }\end{array}$ & Permasalahan Krusial \\
\hline 1 & $\begin{array}{c}\text { Tertib } \\
\text { Hukum } \\
\text { Nasional }\end{array}$ & $\begin{array}{l}\text { Diaturnya persoalan- } \\
\text { persoalan terkait wilayah } \\
\text { agama yang seharusnya } \\
\text { menjadi domain pemerintah } \\
\text { pusat berdasarkan Undang- } \\
\text { undang No. } 32 \text { Tahun } 2004 \\
\text { tentang Pemerintahan } \\
\text { Daerah. Perda secara } \\
\text { hierarki berada dibawah } \\
\text { UU, sehingga ia tidak boleh } \\
\text { bertentangan dengan UU } \\
\text { (vide UU No. } 12 \text { Tahun } \\
2011 \text { tentang Pembentukan } \\
\text { Peraturan Perundang- } \\
\text { undangan) }\end{array}$ \\
\hline$\overline{22}$ & $\begin{array}{l}\text { Materi/ } \\
\text { Muatan } \\
\text { Perda }\end{array}$ & $\begin{array}{l}\text { Perda berbasis syari'ah } \\
\text { mengatur masalah } \\
\text { agama, bukan domain } \\
\text { pengaturan melalui Perda. } \\
\text { Perda Berbasis Syari'ah } \\
\text { yang mengatur hubungan } \\
\text { manusia dengan Tuhan. } \\
\text { Hukum positif mengatur } \\
\text { hubungan manusia dengan } \\
\text { manusia. }\end{array}$ \\
\hline$\overline{3}$ & $\begin{array}{c}\text { Legal } \\
\text { Drafting }\end{array}$ & $\begin{array}{l}\text { Pencantuman sumber } \\
\text { hukum Perda berupa Al } \\
\text { Qur'an dan As Sunnah }\end{array}$ \\
\hline
\end{tabular}

undangan, hendaknya dihindari adanya kepentingan yang teramat kental oleh kelompok tertentu yang dapat membahayakan nilai-nilai kebangsaan dan kenusantaraan. 


\begin{tabular}{|c|c|c|}
\hline 4 & Sanksi & $\begin{array}{l}\text { Tidak boleh menerapkan } \\
\text { sanksi pidana dan/atau } \\
\text { denda melebihi ketentuan } \\
\text { dalam Undang-undang } \\
\text { No. } 32 \text { tahun } 2004 \text { tentang } \\
\text { Pemerintahan Daerah. } \\
\text { Penerapan sanksi diluar } \\
\text { yang diatur dalam Undang- } \\
\text { undang No. } 32 \text { tahun } 2004 \\
\text { tentang Pemerintahan } \\
\text { Daerah tidak dibenarkan, } \\
\text { termasuk sanksi-sanksi yang } \\
\text { sesuai dengan hukum Islam } \\
\text { (Syariah) }\end{array}$ \\
\hline 5 & $\begin{array}{c}\text { Etika-Moral } \\
\text { Hukum }\end{array}$ & $\begin{array}{l}\text { Prioritas pembentukan } \\
\text { Perda } \\
\text { La t a } \mathrm{r} \text { b e la k a } \mathrm{g} \\
\text { pembentukan Perda }\end{array}$ \\
\hline
\end{tabular}

Perda barbasis syari'ah tidak dapat langsung dikatakan baik atau tidak menurut hukum, begitu juga tidak dapat dikatakan sejalan atau bertentangan dengan peraturan perundang-undangan yang ada. Ada beberapa parameter yang dapat dilakukan untuk melakukan penilaian, yaitu dengan cara Eksekutif Review yang dilakukan oleh Kementrian Dalam Negeri, Judicial Review dilakukan oleh Mahkamah Agung dan Legislatif Review oleh Lembaga Legislatif. Melalui parameter tersebut dapat dilihat apakah Perda-perda berbasis syari'ah dimaksud sebagai bagian dari peraturan perundang-undangan yang ada di Indonesia.

\section{Daftar Pustaka}

Abdurrahman. Studi Tentang Undang-undang Sultan Adam 1835, STIH Sultan Adam, Banjarmasin, 1989.

Halidi Yusuf, Ulama Besar Kalimantan Selatan; Syekh Muhammad Arsyad

Al Banjari, (Banjarmasin; Aulia, 1980) hlm 21.

Hamidi Jazim, Pembentukan Peraturan Perundangundangan Dalam Sorotan, Cetakan Pertama, Tata Nusa, Jakarta, 2005.
Kaelani, Najib, Islam dan Perlawanan di Kalimantan Selatan dan Tengah pada abad 19 dan awal abad 20, Pusat Studi dan Pengembangan Borneo, Kalimantan Selatan, 2002.

Mahfud MD., Moh., Politik Hukum di Indonesia, LP3ES, Jakarta, 1998.

, Membangun Politik Hukum Menegakan Konstitusi, Cetakan Kedua, Raja Grafindo Persada, Jakarta, 2011.

, Perdebatan Hukum Tata Negara Pasca Amandemen Konstitusi, Cetakan Kedua, Raja Grafindo Persada, Jakarta, 2011.

, Dasar dan Struktur Ketatanegaraan Indonesia, UII Press, Yogyakarta, 1993

Muzainah, Gusti, Asas Kemanfaatan tentang Kedudukan Perempuan dalam Hukum Waris Adat Masyarakat Banjar (Yogyakarta, Pustaka Akademika, 2016)

Makalah, Pidato Pengukuhan dan Laporan Penelitian.

Abdurrahman, Studi Tentang UU Sultan Adam Suatu Tinjauan Tentang Perkembangan Hukum Dalam Masyarakat dan Kerajaan Banjar Pada Abad ke 19, Makalah

Attamimi, A Hamid S, Teori Perundang-undangan Indonesia, Pidato diucapkan pada Upacara Pengukuhan Jabatan Guru Besar Tetap Pada Fakultas Hukum Universitas Indonesia, di Jakarta pada tanggal 25 April 1992.

Rais, M. Amien, "Negara dan Masyarakat dalam Sistem Religio Politik Islam". Makalah disampaikan dalam diskusi Konsep Negara dalam Islam di Fakultas Hukum UII pada 4 Oktober 1987.

Sahlan, Alwi, "Perda Ramadhan: Tidak Memaksa Berpuasa", dalam Mukhtar Sarman, Mencari Kebenaran Menuai Kecaman; Dibalik Kontroversi Perda Ramadhan, Banjarmasin, PK2PD \& LK3, 2006.

Soemantri, Sri, "Beberapa Catatan Terhadap Proposal Penelitian Tentang Aspek Hukum Inisiatif DPR Dalam Penyusunan UU", Makalah, 1998.

Tim Peneliti dan Penulis Pemerintah Provinsi Kalimantan Selatan, Urang Banjar dan Kebudayaan, Banjarmasin, 2005. 
Usman, Gazali, Kerajaan Banjar Sejarah Perkembangan Politik, Ekonomi Perdagangan dan Agama Islam, Universitas Lambung Mangkurat, Banjarmasin, 1994. 